\title{
Susceptibility of Pseudomonas aeruginosa biofilm to alpha-helical peptides: D-enantiomer of LL-37
}

\author{
Scott N. Dean' ${ }^{1}$ Barney M. Bishop ${ }^{2}$ and Monique L. van Hoek $k^{3,4 *}$ \\ 1 Department of Biology, George Mason University, Manassas, VA, USA \\ ${ }^{2}$ Department of Chemistry and Biochemistry, George Mason University, Manassas, VA, USA \\ ${ }^{3}$ School of Systems Biology, George Mason University, Manassas, VA, USA \\ ${ }^{4}$ National Center for Biodefense and Infectious Diseases, George Mason University, Manassas, VA, USA
}

Edited by:

Dara Frank, Medical College of

Wisconsin, USA

Reviewed by:

Eliana Drenkard, Massachusetts General Hospital/Harvard Medical School, USA

Jimmy Feix, Medical College of Wisconsin, USA

*Correspondence:

Monique L. van Hoek, School of Systems Biology, National Center for Biodefense and Infectious Diseases, George Mason University, MS $1 \mathrm{H} 8$, 10910 University B/vd, Manassas, VA 20110, USA.

e-mail:mvanhoek@gmu.edu
Pseudomonas aeruginosa is a highly versatile opportunistic pathogen and its ability to produce biofilms is a direct impediment to the healing of wounds and recovery from infection. Interest in anti-microbial peptides (AMPs) has grown due to their potential therapeutic applications and their possible use against antibiotic resistant bacteria. LL-37 is the only cathelicidin expressed by humans. In this study, we tested LL-37 and the effect of a protease-resistant LL-37 peptide mimetic, the peptide enantiomer D-LL-37, for anti-microbial and anti-biofilm activity against $P$. aeruginosa. Both forms of the peptide were equally effective as AMPs with similar killing kinetics. Circular dichroism spectra were obtained to demonstrate the chirality of D- and L-LL-37, and the trypsin resistance of D-LL-37 was confirmed. The helical cathelicidin from the cobra Naja atra (NA-CATH), and synthetic peptide variations (ATRA-1, ATRA-2, NA-CATH:ATRA1-ATRA1) were also tested. Although the cobra cathelicidin and related peptides had strong anti-microbial activity, those tested did not inhibit Pseudomonas biofilm formation, neither did control peptides. Both D- and L-LL37 inhibited the attachment of Pseudomonas to a 96-well plate and decreased the amount of pre-formed (established) biofilm. D-LL-37 is able to promote Pseudomonas motility and decrease biofilm formation by altering the rate of twitching as well as by downregulating the expression of the biofilm-related genes, $r h / A$ and $r h / B$, similar to L-LL-37. Both L- and D-LL-37 protected Galleria mellonella in vivo against Pseudomonas infection, while NACATH:ATRA1-ATRA1 peptide did not. This study demonstrates the ability and equivalence of D-LL-37 compared to L-LL-37 to promote bacterial twitching motility and inhibit biofilm formation, and protect against in vivo infection, and suggests that this peptide could be a critical advancement in the development of new treatments for $P$. aeruginosa infection.

Keywords: Pseudomonas, biofilm, cathelicidin, enantiomer, mimetic, protease-resistance, chiral

\section{INTRODUCTION}

Pseudomonas aeruginosa, a Gram-negative bacterium, is a major cause of hospital-associated infections, causing $\sim 10 \%$ of nosocomial infections (Hancock and Speert, 2000), with a sepsis mortality rate of nearly 50\% (Bone, 1993). This opportunistic pathogen can cause pneumonia, catheter-associated and urinary tract infections, and sepsis in wounded patients and those who are immunocompromised (Van Delden and Iglewski, 1998). P. aeruginosa is the most clinically relevant pulmonary pathogen in patients with cystic fibrosis, causing chronic infections, and is the most common cause of fatal lung disease (Richards et al., 1999), as well as the most frequently recorded cause of hospital-acquired pneumonia, with an increasing number of these cases involving antibiotic resistant strains (Rello et al., 1993; Heyland et al., 1999).

In order for the opportunistic pathogen $P$. aeruginosa to infect a host, it requires a break in the innate immunological defenses.

Abbreviations: AMP, anti-microbial peptide; CAMP, cationic anti-microbial peptide; CFU, colony forming unit; EC50, half-maximal effective concentration; MIC, minimum inhibitory concentration; TFE, trifluoroethanol.
Once established within the host, the ability of $P$. aeruginosa to form biofilm is a signature characteristic for it to become a chronic infection (Hoiby et al., 2001; Singh et al., 2002). This property has made Pseudomonas a model organism in the study of biofilm formation. Biofilms, non-motile communities enveloped in an exopolysaccaride and extracellular protein secretion that enhances survival, are often physically resistant to anti-microbial agents and host immune responses (Stewart et al., 2001; Donlan and Costerton, 2002; Drenkard and Ausubel, 2002). It has been shown that biofilm formation can be a pathogen's defensive reaction to the presence of antibiotics. Specifically, subinhibitory concentrations of antibiotics can initiate the production of the exopolysaccharide matrix by $P$. aeruginosa, and stimulate increases in biofilm volume (Rachid et al., 2000; Bagge et al., 2004). The clinical use of current antibiotics at concentrations effective for eliminating biofilms would result in significant systemic side effects, limiting their utility in such cases (Whatley et al., 2006). In addition to $P$. aeruginosa infections in burn victims (Ressner et al., 2008), examples of biofilm-associated infections include: pneumonia and cystic fibrosis (Hoiby et al., 2001; Singh et al., 2002), chronic 
wounds such as diabetic foot ulcers, sinus and ear infections, and endocarditis (Costerton et al., 1999; Prince, 2002; Dieter, 2004; Kaneko et al., 2007).

Anti-microbial peptides (AMPs) are critical components of innate immunity in humans, contributing to our first line of defense against infection (Zasloff, 2002). The cathelicidin family of AMPs range from 12 to 80 amino acid residues in length, and are identified based on a conserved $\mathrm{N}$-terminal domain, the cathelin domain, present in the inactive precursor peptide (cleaved from the active peptide) within the granules of natural killer $\mathrm{T}$ cells, in the mucosal epithelia of the lungs, and other sites (Ganz and Weiss, 1997). The sequence diversity of cathelicidins translates into the peptides demonstrating structural diversity, which can be grouped into sub-classes based on shared structural features. Alpha-helical cathelicidins, which adopt amphipathic helical conformations when interacting with membranes, are the largest of the cathelicidin structural classes. Our knowledge of their structural and functional properties is largely based on observations from the single, highly studied human cathelicidin, LL-37 (Gennaro et al., 1998).

The single human cathelicidin LL-37 is derived from the C-terminus of the human CAP-18 protein. It is a 37 residue cationic peptide which forms an alpha-helix when in contact with bacterial membranes. This peptide has broad-spectrum antimicrobial activity against Gram-negative and Gram-positive bacteria, including against $P$. aeruginosa (EC50 of $2.8 \pm 1.3 \mu \mathrm{g} / \mathrm{ml}$; Bals et al., 1998; Turner et al., 1998; Travis et al., 2000; Saiman et al., 2001; Bucki et al., 2004; Gordon et al., 2005). However, multi-drug resistant $P$. aeruginosa strains exhibit reduced sensitivity to several AMPs (Ouhara et al., 2008), demonstrating the need to identify more effective AMPs. In order to develop additional AMPs we decided to test the impact of peptide chirality on the anti-microbial effectiveness of LL-37. We synthesized a D-LL37 peptide, in which each amino acid residue of the naturally occurring L-isomer had been replaced with the corresponding D-amino acid reside. This peptide exhibits immunostimulatory activity more potent than that of LL-37 (induction of IL-8 in keratinocytes and promoting fibroblast proliferation; Braff et al., 2005a), which suggests the interaction between the cathelicidin peptide and the host cellular membrane or intracellular targets may be complex, perhaps involving receptors that exhibit chiral discrimination and recognition.

There are only a few studies that show peptides with antibiofilm activity against $P$. aeruginosa. We and others have demonstrated the anti-biofilm activity of synthetic peptide mimics of AMPs against Staphylococcus aureus, and other pathogens (Beckloff et al., 2007; Pollard et al., 2009; Amer et al., 2010; Dean et al., 2011; Leszczynska et al., 2011). In vivo, a 24-residue LL37-derived AMP was shown to degrade established $P$. aeruginosa biofilm in an animals' nasopharynx, however the significant effect required $2.5 \mathrm{mg} / \mathrm{ml}$ of peptide, a high concentration for therapeutic use (Chennupati et al., 2009). Overhage et al. (2008) demonstrated that $4 \mu \mathrm{g} / \mathrm{ml} \mathrm{LL}-37$ was able to reduce pre-formed Pseudomonas biofilm formation in vitro, and that LL-37 treatment affected gene expression of many biofilm-related genes in P. aeruginosa PAO1, including the significant downregulation of $r h l A$ and rhlB expression.
A recently identified helical cathelicidin from the elapid snake Bungarus fasciatus (BF) was found to be antimicrobial against P. aeruginosa (MIC of $1.2 \mu \mathrm{g} / \mathrm{ml}$; Wang et al., 2008). A related cathelicidin peptide that has shown to be a potent anti-microbial against many bacteria was discovered in the elapid snake Naja atra (NA), the Chinese Cobra, but has not been previously tested against $P$. aeruginosa. We previously observed that the 39 residue amino acid sequence of the NA cathelicidin (NA-CATH) contains an imperfect, repeated 11 residue motif (ATRA), larger than what was first described by Zhao et al. (Zhao et al., 2008; Amer et al., 2010; de Latour et al., 2010). We previously designed and synthesized a peptide called NA-CATH:ATRA1-ATRA1 to explore the significance of the conserved residues within the ATRA motif for anti-microbial and anti-biofilm activity against Staphylococcus aureus (Dean et al., 2011). In this study, we test the ATRA family of peptides against Pseudomonas. In addition, we have synthesized the D-form of LL-37 as a peptide mimetic to address the protease-sensitivity concern stated below.

Although AMPs are promising for potential clinical use, and their in vivo abilities to combat in vivo bacterial infections have been demonstrated (Wilson et al., 1999; Nizet et al., 2001; Moser et al., 2002; Yasin et al., 2004; Lopez-Leban et al., 2010) there are some challenges that have prevented their widespread use. First, mammalian peptides, such as the human cathelicidin LL37 , are commonly sensitive to high salt concentrations (Goldman et al., 1997; Johansson et al., 1998). Second, the feasibility of the use of AMPs in the presence of bacterial and host proteases is a considerable challenge. It was found that Pseudomonas biofilms continuously exposed to ciprofloxacin continuously secreted proteases over a period of 4 days (Braff et al., 2005b; Oldak and Trafny, 2005), thus potentially limiting the utility of AMPs. A significant improvement would be to design a protease-resistant peptide, such as D-LL-37, if the D-peptide has the same biological effect as the L-peptide.

Thus, this study will examine the ability of a family of cathelicidins and related small peptides to exert anti-microbial and anti-biofilm effects against $P$. aeruginosa. We will also examine the activity of both the D and L chiral enantiomers of several of the peptides. Finally, we will examine changes in $r h l A$ and $r h l B$ gene expression in the presence of D-LL-37, to determine if the chiral enantiomer is acting through the same mechanism as L-LL-37.

\section{MATERIALS AND METHODS BACTERIAL STRAINS AND MEDIA}

Pseudomonas aeruginosa [ATCC 19429 and ATCC 27853 (a type strain blood isolate), American Type Culture Collection, Manassas, VA, USA] were grown in Nutrient Broth (Difco Laboratories, Detroit, MI, USA) at $37^{\circ} \mathrm{C}, 24 \mathrm{~h}$ with shaking at $200 \mathrm{rpm}$. The $\mathrm{CFU} / \mathrm{ml}$ was determined by dilution plating on Nutrient Agar plates. For the anti-microbial assays, frozen enumerated aliquots were thawed immediately before use.

\section{ANTI-MICROBIAL ASSAYS}

The anti-microbial activity of the NA-CATH and NACATH:ATRA1-ATRA1 (AAPPTEC, Louisville, KY, USA), the variations on the ATRA peptides (Genscript, Piscataway, NJ, USA), LL-37 (AnaSpec 61302), and D-LL-37 (Lifetein, South Plainfield, 
NJ, USA) against $P$. aeruginosa (ATCC 19429) were determined as previously described, with some modification (Han et al., 2008; Papanastasiou et al., 2009). The sequences and net charges of the peptides are shown in Table 1.

In a 96-well plate, $1 \times 10^{5} \mathrm{CFU}$ per well of bacteria were incubated with different peptide concentrations (in serial dilutions of 1:10 or 1:5 per dilution) in a solution of buffer containing $10 \mathrm{mM}$ sodium phosphate at $\mathrm{pH} 7.4\left(3 \mathrm{~h}, 37^{\circ} \mathrm{C}\right)$. Serial dilutions were then carried out in $1 \times$ Dulbecco's PBS and plated in triplicate on Nutrient Agar plates, incubated $\left(37^{\circ} \mathrm{C}, 24 \mathrm{~h}\right)$ and CFUs counted. Bacterial survival at each peptide concentration was calculated as previously described (Amer et al., 2010; de Latour et al., 2010) based on the percentage of colonies in each experimental plate relative to the average number of colonies observed for assay cultures lacking peptide. The peptide concentration required to kill $50 \%$ of the $P$. aeruginosa in the anti-microbial assay cultures (EC50) was determined by plotting percent survival as a function of the log of peptide concentration $\left(\log _{10}\right)$ and fitting the data using GraphPad Prism 5 (GraphPad Software Inc., San Diego, CA, USA), using the equation:

$Y=$ Bottom $+($ Top - Bottom $) /\left(1+10^{[(\operatorname{logEC} 50-X) \times \text { Hill slope })]}\right)$

where $Y$ corresponds to bacterial survival (in percentage) at a given peptide concentration $(\mu \mathrm{g} / \mathrm{ml})$, with $X$ being the logarithm of that concentration. In the equation, "Top" and "Bottom" refers to the upper and lower boundaries, and were constrained to values $<100 \%$ and $>0 \%$, respectively. For graphing purposes, samples that had no peptide were plotted at $10^{-9} \mu \mathrm{g} / \mathrm{ml}$ peptide. EC50 values were determined by fitting the data from the anti-microbial assays to a standard sigmoidal dose-response curve. In Figure 1, only the range from -2.5 to 2.5 on the $\mathrm{x}$-axis is shown. Each experiment was repeated at least twice, and a representative experiment is shown, for clarity. $95 \%$ confidence intervals (CI) are reported to indicate the error of each EC50 determination.

In order to study the in vitro killing kinetics of the LL-37, D-LL-37, and NA-CATH:ATRA1-ATRA1 peptides, cultures of $P$. aeruginosa (ATCC 19429) were incubated with the peptides in $10 \mathrm{mM}$ sodium phosphate. The concentrations used in the assay were: $1.0 \mu \mathrm{g} / \mathrm{ml}$ of LL-37, $1.0 \mu \mathrm{g} / \mathrm{ml}$ of NA-CATH, and $0.73 \mu \mathrm{g} / \mathrm{ml}$ of NA-CATH:ATRA1-ATRA1. The anti-microbial activity of the peptides was determined over a period of $3 \mathrm{~h}$, and plated in triplicate, as previously described (Amer et al., 2010).

\section{SPECTROSCOPY}

Circular dichroism (CD) spectra of the peptides were collected using Jasco J-815 spectropolarimeter. Samples were allowed to equilibrate for $10 \mathrm{~min}$ at $25^{\circ} \mathrm{C}$ prior to data collection in a $0.1-\mathrm{cm}$ path length cuvette, with a chamber temperature $25^{\circ} \mathrm{C}$ throughout each scan. Spectra were collected from 190 to $260 \mathrm{~nm}$ using $0.2-\mathrm{nm}$ intervals; three scans per sample were averaged. All peptides were analyzed at $250 \mu \mathrm{g} / \mathrm{ml}$ in $10 \mathrm{mM}$ sodium phosphate $(\mathrm{pH} 7), 50 \%$ $(\mathrm{v} / \mathrm{v})$ trifluoroethanol (TFE) in $10 \mathrm{mM}$ sodium phosphate $(\mathrm{pH} 7$; Lee et al., 2003).

\section{BIOFILM PRODUCTION}

Biofilm production was measured as previously described (Durham-Colleran et al.) with the following modifications. P. aeruginosa (ATCC 19429; $1 \times 10^{5} \mathrm{CFU}$ ) in $200 \mu \mathrm{l}$ of Trypticase Soy Broth was incubated with peptide at concentrations of 1.0, 0.1 , and $0.01 \mu \mathrm{g} / \mathrm{ml}$ for $24 \mathrm{~h}, 37^{\circ} \mathrm{C}$. Optical density of the cultures $(\mathrm{OD} 600 \mathrm{~nm})$ at $24 \mathrm{~h}$ was determined prior to staining as a measure of bacterial growth. Six wells were used for each peptide concentration $(n=6)$. Biofilm production was measured using the crystal violet stain technique (Durham-Colleran et al.).

\section{BIOFILM ATTACHMENT ASSAY}

The biofilm attachment assay was performed using an overnight culture $\left(\mathrm{OD}_{600}=1.0\right)$ P. aeruginosa (ATCC 19429 and ATCC $27853)$ in $200 \mu \mathrm{l}$ of TSB was incubated with either D- or L-LL37 at $1 \mu \mathrm{g} / \mathrm{ml}$ for $1 \mathrm{~h}, 37^{\circ} \mathrm{C}$. The optical density of the cultures $(570 \mathrm{~nm})$ at $1 \mathrm{~h}$ was determined prior to staining as a measure of bacterial growth. Twelve wells were used for each peptide concentration $(n=12)$. Biofilm production was measured using the crystal violet stain technique (Durham-Colleran et al.).

\section{PRE-FORMED BIOFILM ASSAY}

The pre-formed biofilm assay was performed using $P$. aeruginosa (ATCC 19429 and ATCC 27853; $1 \times 10^{5} \mathrm{CFU}$ ) in $200 \mu \mathrm{l}$ of TSB was incubated for $24 \mathrm{~h}, 37^{\circ} \mathrm{C}$. Following the formation of an established biofilm at $24 \mathrm{~h}$, the biofilm was treated with either D- or L-LL-37 at $1 \mu \mathrm{g} / \mathrm{ml}$ and incubated for $24 \mathrm{~h}, 37^{\circ} \mathrm{C}$. The optical density of the cultures $(570 \mathrm{~nm})$ at $48 \mathrm{~h}$ was determined prior to staining as a measure of bacterial growth. Twelve wells were used for each peptide concentration $(n=12)$. Biofilm production was measured using the crystal violet stain technique (Durham-Colleran et al.).

Table 1| Peptides used in this study.

\begin{tabular}{llr}
\hline Anti-microbial peptide & Sequence & Net charge \\
\hline NA-CATH & KRFKKFFKKLKNSVKKRAKKFFKKPKVIGVTFPF & 15 \\
NA-CATH:ATRA1-ATRA1 & KRFKKFFKLKNSVKKRFKKFFKKLKVIGVTFPF & 15 \\
ATRA-1 & KRFKKFFKKLK-NH2 & 8 \\
ATRA-2 & KRAKKFFKKPK-NH2 & 8 \\
LL-37 & LLGDFFRKSKEKIGKEFKRIVQRIKDFLRNLVPRTES & 6 \\
D-LL-37 & LLGDFFRKSKEKIGKEFKRIVORIKDFLRNLVPRTES & 6 \\
mCRAMP & GLLRKGGEKIGEKLKKIGQKIKNFFOKLVPOPEO & 6 \\
Scrambled LL-37 & GLKLRFEFSKIKGEFLKTPEVRFRDIKLKDNRISVOR & 6 \\
\hline
\end{tabular}

This table indicates the sequence and charges of the anti-microbial peptides used. The ATRA motif is indicated in BOLD. 

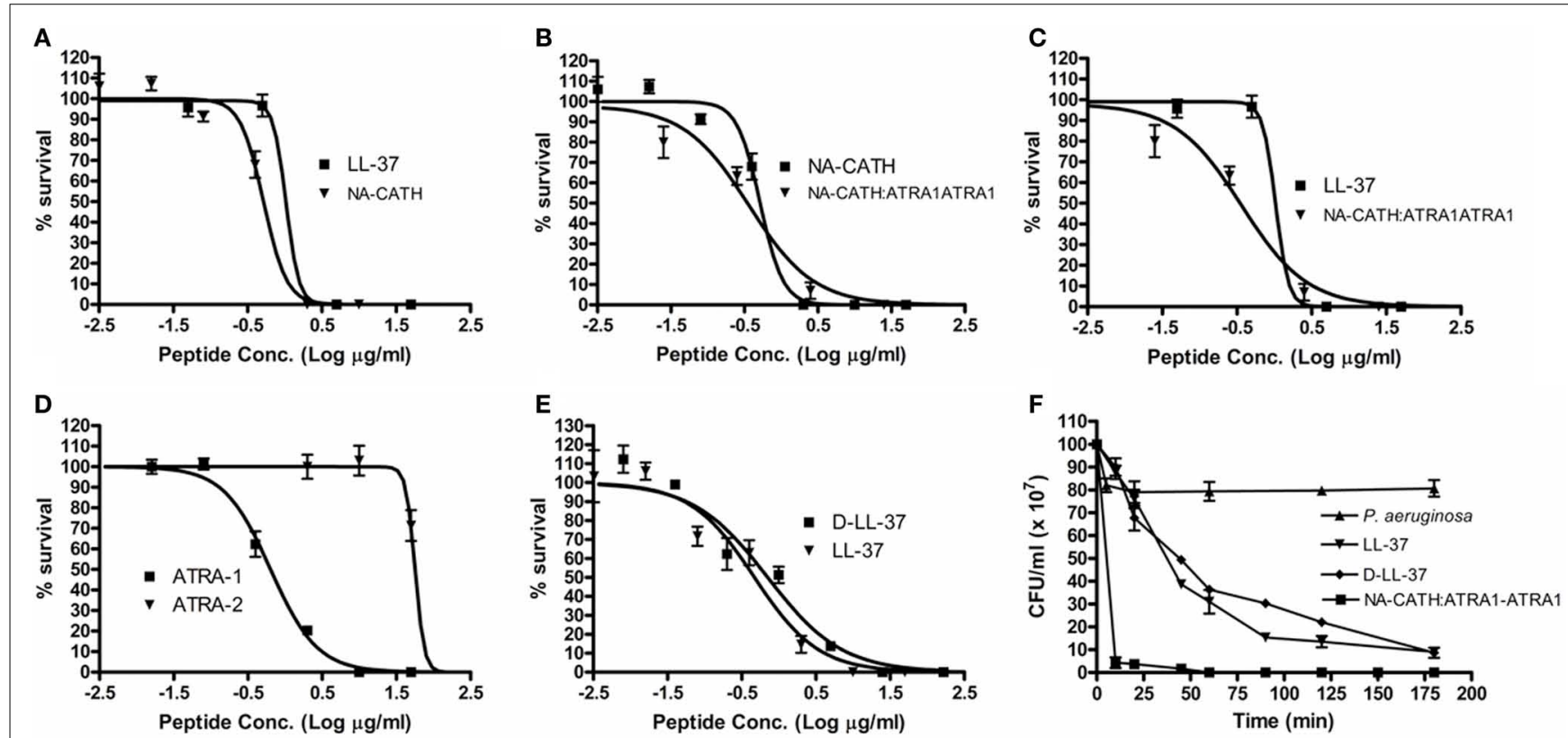

FIGURE 1 | Effectiveness of anti-microbial peptides against P. aeruginosa. Percent (\%) survival was calculated by counting CFUs, after $3 \mathrm{~h}$ incubations with various peptide concentrations in $10 \mathrm{mM}$ sodium phosphate (pH 7.4). (A) The EC50s were found to be $0.52 \mu \mathrm{g} / \mathrm{ml}$ for NA-CATH and $0.74 \mu \mathrm{g} / \mathrm{ml}$ for LL-37. (B) EC50s were found to be $0.37 \mu \mathrm{g} / \mathrm{ml}$ for NA-CATH:ATRA1-ATRA1 and $0.52 \mu \mathrm{g} / \mathrm{ml}$ for NA-CATH. (C) EC50s were found to be $0.37 \mu \mathrm{g} / \mathrm{ml}$ for NA-CATH:ATRA1-ATRA1 and $0.47 \mu \mathrm{g} / \mathrm{ml}$ for LL-37. (D) EC50s were found to be $0.64 \mu \mathrm{g} / \mathrm{ml}$ for ATRA-1 and $62.8 \mu \mathrm{g} / \mathrm{ml}$ for ATRA-2. (E) EC50s were found to be $0.72 \mu \mathrm{g} / \mathrm{ml}$ for D-LL-37 and $0.47 \mu \mathrm{g} / \mathrm{ml}$ for LL-37. (F) The peptides were incubated in $10 \mathrm{mM}$ sodium phosphate with $P$. aeruginosa at the EC50 $(0.47 \mu \mathrm{g} / \mathrm{ml}$ for LL-37, $0.72 \mu \mathrm{g} / \mathrm{ml}$ for D-LL-37 and $0.37 \mu \mathrm{g} / \mathrm{ml}$ for NA-CATH:ATRA1-ATRA1). Killing kinetics assays were plated in triplicate time points over $3 \mathrm{~h}$.

\section{MOTILITY ASSAYS}

Twitching motility of $P$. aeruginosa (ATCC 19429) was measured after $16,20,24$, and $48 \mathrm{~h}$ of incubation at $37^{\circ} \mathrm{C}$ on LB plates containing 1\% (wt/vol) agar and LB broth (Overhage et al., 2008). $P$. aeruginosa cells were spot inoculated using a needle, and zone diameters were determined by measuring at least three times across the zone. Assays were carried out with $4 \mu \mathrm{g} / \mathrm{ml}$ of either D-LL-37 or L-LL-37, and controls. $(n=30)$.

\section{EXAMINATION OF D- AND L-LL-37 SENSITIVITY TO TRYPSIN}

The proteolytic stability of the enantiomers, L- and D-LL-37, was assessed in the presence of trypsin. The peptides $(18 \mu \mathrm{g})$ were dissolved in $90 \mu \mathrm{l}$ of water. Then, either water or $0.05 \%$ trypsin $(10 \mu \mathrm{l})$ was added to the peptide solutions, and incubated at $37^{\circ} \mathrm{C}$ for $1 \mathrm{~h}$. After incubation, $10 \mu \mathrm{l}$ aliquots were taken into an $18 \%$ Tris-Glycine gel. After running the gel, the gel was transferred to a clean tray and a silver stain was performed.

\section{GALLERIA MELLONELLA EXPERIMENT}

The Galleria mellonella (wax moth caterpillars) were obtained from Vanderhorst Wholesale (Saint Marys, OH, USA). Eight to twelve caterpillars of equal size/weight were randomly assigned to each group. A 1-ml tuberculin syringe was used to inject $10 \mu \mathrm{l}$ of $1 \times 10^{3} \mathrm{CFU} / \mathrm{ml}$ of $P$. aeruginosa into each caterpillar's central cavity (hemocoel). The caterpillars were then immediately injected with $10 \mu \mathrm{l}$ of either PBS, $5 \mu \mathrm{g}$ of ciprofloxacin, $10 \mu \mathrm{g}$ D- or L-LL37, or $10 \mu \mathrm{g}$ of NA-CATH:ATRA1-ATRA1 in the dorsal side of the caterpillar. Caterpillar control groups included: injected with only
PBS, ciprofloxacin, or AMPs. The insects were then observed daily for their survival status.

\section{ANALYSIS OF $r h I A$ AND $r h l B$ GENE EXPRESSION IN THE PRESENCE OF D- AND L-LL-37 BY qRT-PCR}

Quantitative real time RT-PCR analysis was performed in a MyiQ Single Color Real-Time PCR Detection System (BioRad Laboratories). $1 \times 10^{3}$ CFUs of $P$. aeruginosa (ATCC 19429) were incubated in $2 \mathrm{ml}$ of TSB at $37^{\circ} \mathrm{C}$ for $24 \mathrm{~h}$. In duplicate, from two independent experiments, RNA from biofilm formed in an untreated control, D-LL-37 $(1 \mu \mathrm{g} / \mathrm{ml})$ and LL-37 $(1 \mu \mathrm{g} / \mathrm{ml})$ was isolated (RNAeasy Mini Kit, Qiagen) and reverse transcribed (Super Script ${ }^{\mathrm{TM}}$ III Reverse Transcriptase, Invitrogen). The protocol was performed as previously described (Amer et al., 2010).

The primer sequence for $r h l A 5^{\prime}$-TCTGTTGGTATCGGTTTG CAAGGG $-3^{\prime}$ forward and $5^{\prime}$-ACAGCACCACGTTGAAATGTTCG G-3' reverse; the primer sequence for rhlB $5^{\prime}$-CATCGCTCACGAG AAGTACG-3' ${ }^{\prime}$, forward and 5'-GTTGAACTTGGGGTGTACCG-3' were obtained from Invitrogen. The relative levels of transcription was normalized by correcting for rpoD transcription levels.

\section{STATISTICAL ANALYSIS}

Anti-microbial assay measurements were performed in triplicates, biofilm assays done at least in duplicate with $n=6$ each time, and representative experiments are shown. Standard deviations of the mean of each set are represented on each graph. Where the error bars cannot be seen, the error is very small. CI (95\%) is presented for EC50 determinations demonstrating the statistical overlap of 
the data. Statistically significant differences were assessing using Student's $t$ tests.

\section{RESULTS}

\section{ANTI-MICROBIAL PERFORMANCE}

\section{Effect of chirality: $D$ - vs $L$-LL-37 against $P$. aeruginosa}

A common concern against the use of AMPs as potential therapeutics is their potential sensitivity to host or bacterial proteases (Braff et al., 2005b). In order to generate a protease-resistant peptide mimetic of the human cathelicidin (Wade et al., 1990), we synthesized an all-D-amino acid version of LL-37. The anti-microbial EC50 for D-LL-37 against P. aeruginosa (ATCC 19429) was determined to be $0.72 \mu \mathrm{g} / \mathrm{ml}$, compared to $0.47 \mu \mathrm{g} / \mathrm{ml}$ for wild-type LL-37 (Table 2; Figure 1E); there is not a significant difference in anti-microbial activity between them by examining the $95 \%$ CIs. Additionally, D- and L-LL-37 display similar killing kinetics over the 3 h duration of a killing kinetics assay against $P$. aeruginosa (ATCC 19429) Figure 1F.

\section{Small synthetic peptides demonstrate anti-microbial activity against $\boldsymbol{P}$. aeruginosa}

Pseudomonas aeruginosa (ATCC 19429) was also subjected to treatment with two short, synthetic peptides (Table 1), ATRA-1 and ATRA-2. These two ATRA peptides differ by two residues at the 3rd (F/A) and 10th (L/P) position. This has been shown to affect the anti-microbial activity of those peptides against Francisella novicida, Escherichia coli (Amer et al., 2010), Aggregatibacter actinomycetemcomitans (de Latour et al., 2010), and Staphylococcus aureus (Dean et al., 2011). The EC50 values of ATRA-1 and ATRA-2 were determined to be statistically different $(p<0.05$, Student's $t$ test) at 0.64 and $62.8 \mu \mathrm{g} / \mathrm{ml}$, respectively (Table 2; Figure 1D). These two peptides have the same net charge of +8 , highly similar sequence and both are 11 amino acid residues in length.

\section{LL-37 and NA-CATH-derived peptide are anti-microbial against P. aeruginosa}

The anti-microbial effectiveness of NA-CATH was tested against P. aeruginosa (ATCC 19429), and the performance of this peptide was compared to that of the well-studied cathelicidin LL-37. The EC50 for NA-CATH was found to be $0.52 \mu \mathrm{g} / \mathrm{ml}$ (Figure 1A). The peptide NA-CATH:ATRA1-ATRA1 incorporates modifications to the NA-CATH sequence in which the second ATRA motif has been changed to match the sequence of the first ATRA motif (Table 2) thus creating a perfect repeat. This synthetic cathelicidin had an EC50 value that was determined to be $0.37 \mu \mathrm{g} / \mathrm{ml}$, not statistically more effective against $P$. aeruginosa (ATCC 19429) than the NA-CATH parent peptide (Figure 1B), or LL-37 (Figure 1C). We previously demonstrated that the alterations made to NA-CATH to create NA-CATH:ATRA1-ATRA1 resulted in a statistically significant ( $p<0.05$, Student's $t$ test) improvement in anti-microbial activity against $S$. aureus (Dean et al., 2011).

In agreement with reported potencies (Gordon et al., 2005), we found that the EC50 for LL-37 is $0.47 \mu \mathrm{g} / \mathrm{ml}$. This is within the range of the level of LL-37 reported in human plasma $(1.18 \mu \mathrm{g} / \mathrm{ml}$; Sorensen et al., 1997), suggesting that this is a physiologically relevant potency of LL-37.

\section{INHIBITION OF ATTACHMENT AND BIOFILM FORMATION, AND DEGRADATION OF ESTABLISHED P. AERUGINOSA BIOFILM AT SUB-ANTI-MICROBIAL CONCENTRATIONS}

A concern of the utility of AMPs as potential therapeutics is the sensitivity of the anti-microbial activity to salt. Multiple studies have shown that LL-37 demonstrates reduced anti-microbial action in environments with high ionic concentrations (Travis et al., 2000; Cox et al., 2003) such as in physiologic salt concentration (123-150 mM NaCl). However, LL-37 can inhibit biofilm formation by P. aeruginosa PAO1 (Overhage et al., 2008), S. epidermidis (Hell et al., 2010), F. novicida (Amer et al., 2010), and $S$. aureus in media with high concentrations of salt. LL-37 is reported to be capable of degrading pre-formed biofilms of S. aureus and P. aeruginosa (Altman et al., 2006; Overhage et al., 2008).

In this study, we demonstrate similar salt-independent antibiofilm activity for D-LL-37 against $P$. aeruginosa. We incubated various concentrations of NA-CATH, NA-CATH:ATRA1-ATRA1, LL-37, D-LL-37, mCRAMP, and scrambled LL-37 with $P$. aeruginosa in biofilm experiments in TSB (relatively high salt; $86 \mathrm{mM}$ $\mathrm{NaCl}$ ) for $24 \mathrm{~h}$. Both mCRAMP, a murine-homolog of LL-37 (67\% identical to LL-37 in amino acid sequence), and scrambled LL-37 (identical amino acids in random order) functioned as negative controls for this experiment; the former was previously known to have no inhibitory effect (Overhage et al., 2008). The scrambled version of LL-37, having the same charge and net amino acid composition as LL-37, but lacking significant helical character, showed no inhibition of biofilm formation at any concentration

Table 2 | EC50s of AMPs against P. aeruginosa.

\begin{tabular}{|c|c|c|c|c|}
\hline Anti-microbial peptide & Molecular weight $(\mathrm{g} / \mathrm{mol})$ & $\operatorname{EC50}(\mu \mathrm{g} / \mathrm{ml})$ & $95 \% \mathrm{CI}$ & $\mathrm{EC50}(\mu \mathrm{M})$ \\
\hline NA-CATH & 5885.5 & 0.52 & $0.39-0.69$ & 0.09 \\
\hline NA-CATH:ATRA1-ATRA1 & 5977.6 & 0.37 & $0.21-0.63$ & 0.06 \\
\hline ATRA-2 & 2316.96 & 62.8 & $27.7-949$ & 27.1 \\
\hline LL-37 & 5177.42 & 0.47 & $0.28-0.78$ & 0.09 \\
\hline
\end{tabular}

This table indicates the EC50 of the peptides against P. aeruginosa in an anti-microbial assay. The molecular weight reported here for each peptide reflects the TFA salts of the peptides. These molecular weights were then used to convert the EC50 in $\mu \mathrm{g} / \mathrm{ml}$ to $\mu \mathrm{M}$, to enable comparisons on a molecule-by-molecule basis. 
tested (Figure 2B), thus demonstrating sequence specificity of the anti-biofilm effect.

Figures 2A-C shows that levels of bacterial growth (OD600 nm at $24 \mathrm{~h}$ ) were not decreased even at the peptide concentrations equal to that of its calculated EC50 in $10 \mathrm{mM}$ sodium phosphate.
We could not calculate the MIC because there was no inhibition of growth at any concentration tested, thus MIC $>1 \mu \mathrm{g} / \mathrm{ml}$. When the biofilm production was determined in the presence of varying amounts of peptide, there was significant inhibition of biofilm formation by L- and D-LL-37; all other peptides were
A

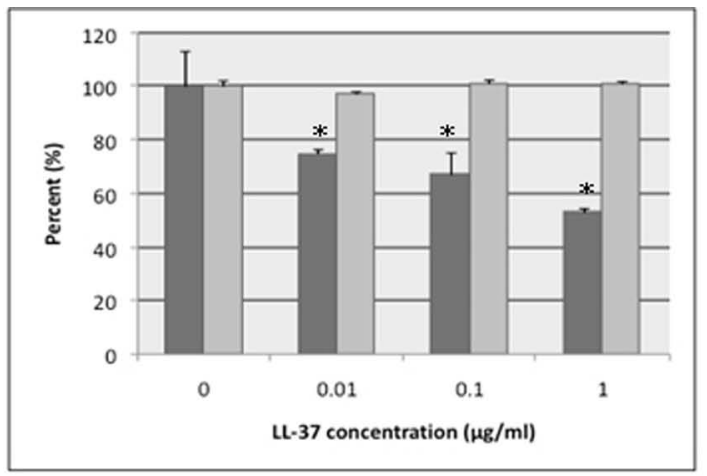

C

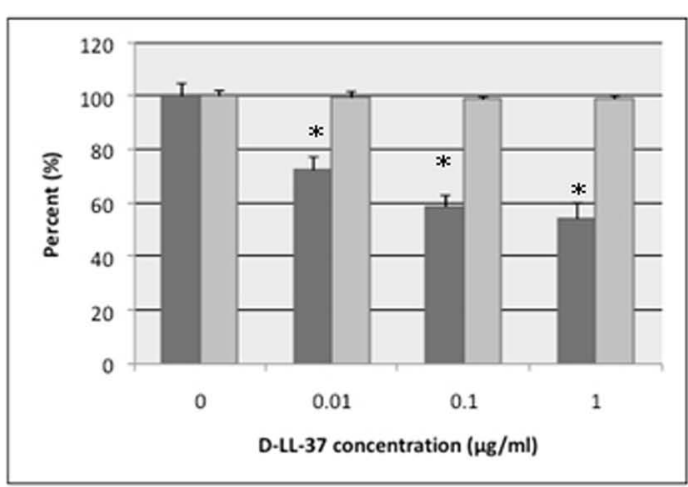

E

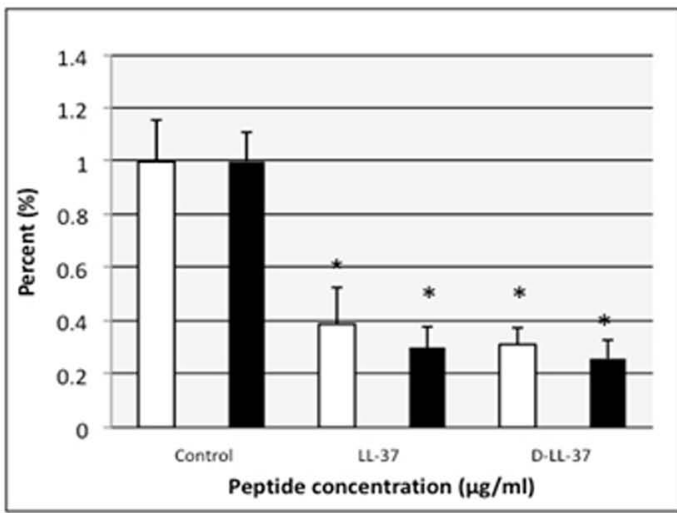

FIGURE 2 | D- and L-LL-37 inhibit biofilm formation and attachment, stimulate twitching motility, and degrade biofilm of $P$ aeruginosa. (A-C) Inhibition of $P$. aeruginosa biofilm formation was demonstrated for $D$ - and L-LL-37 (A,C), while scrambled LL-37, NA-CATH, NA-CATH:ATRA1-ATRA1 (indicated by A1-A1) and mCRAMP all showed a lack of anti-biofilm activity (B). Growth (absorbance at $600 \mathrm{~nm}$ ) is indicated by light gray bars with "0 peptide" control set to $100 \%$. Biofilm detection on a polystyrene 96 -well plate at $37^{\circ} \mathrm{C}$ after $24 \mathrm{~h}$ of growth in TSB was detected as the absorbance of crystal violet stain $(570 \mathrm{~nm})$. Percent biofilm production is indicated by dark gray bars $(n=6)$, relative to " 0 peptide" control. Each experiment is a representative of at least two independent trials. Error bars indicate the standard deviation from

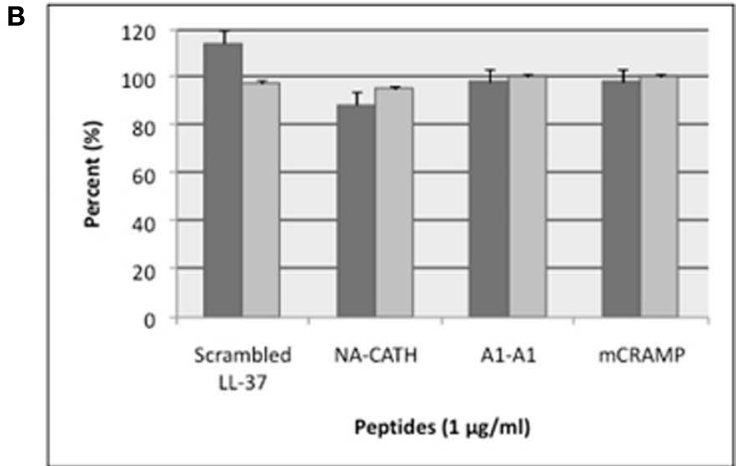

D
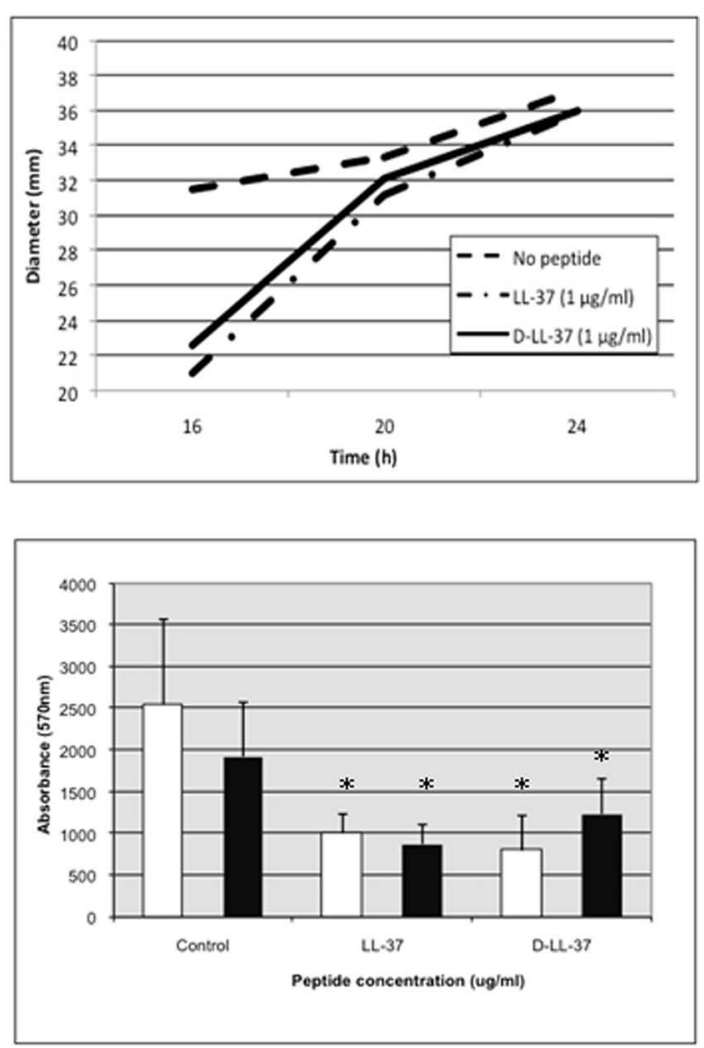

the mean. The asterisk $\left(^{*}\right)$ indicates statistically different than the positive control ( $p<0.01)$. (D) $D$ - and L-LL-37 increased the rate of twitching motility in $P$. aeruginosa. Motility was measured after 16,20 , and $24 \mathrm{~h}$ of incubation at $37^{\circ} \mathrm{C}$ on plates containing $1 \%(\mathrm{wt} / \mathrm{vol})$ agar and LB broth. Plates were inoculated using a needle, and diameters were recorded. Assays were carried out with $4 \mu \mathrm{g} / \mathrm{ml}$ of either D-LL-37 or L-LL-37, and controls. $(n=30)$. (E) Attachment assays were performed in the presence of $1 \mu \mathrm{g} / \mathrm{ml}$ of $D$ - or L-LL-37; ATCC 19429 is indicated by white columns, ATCC 27853 is represented by black columns. (F) Pre-formed biofilm assays were performed in the presence of $1 \mu \mathrm{g} / \mathrm{ml} \mathrm{D}$ - or L-LL-37; ATCC 19429 is indicated by white columns, ATCC 27853 is represented by black columns. 
ineffective. Thus, LL-37 was found to inhibit biofilm formation up to $\sim 50 \%$ of control at $1 \mu \mathrm{g} / \mathrm{ml}$ (Figure 2C). D-LL-37 was also found to be an active anti-biofilm peptide, with maximal biofilm inhibition observed at $1 \mu \mathrm{g} / \mathrm{ml}$, inhibiting $~ 50 \%$ of biofilm formation (Figure 2B).

In addition to showing that D- and L-LL-37 can inhibit the formation of $P$. aeruginosa (ATCC 19429), we determined that D- and L-LL-37 significantly reduces attachment at $1 \mu \mathrm{g} / \mathrm{ml}$ (Figure 2E) after $1 \mathrm{~h}$ for $P$. aeruginosa (ATCC 19429 and ATCC 27853). Suggesting a possible mechanism for biofilm inhibition. The amount of inhibition of attachment ( $\sim 15-22 \%$ for LL-37, and $\sim 39 \%$ for D-LL-37) may not account for the full ability of the peptides to inhibit biofilm formation at the same concentration, but may contribute to this effect.

In order to determine the ability of D- and L-LL-37 to degrade pre-formed biofilm of $P$. aeruginosa (ATCC 19429 and ATCC 27853), the bacteria were allowed to establish biofilm for $24 \mathrm{~h}$, then the wells were treated with either D- or L-LL-37 $(1 \mu \mathrm{g} / \mathrm{ml})$. After incubation with peptide, biofilm production was quantified with the crystal violet stain method (Durham-Colleran et al.), and significant degradation of established $P$. aeruginosa biofilm was observed (Figure 2F).

\section{D- AND L-LL-37 STIMULATES TWITCHING MOTILITY}

Twitching motility is required for the formation of Pseudomonas biofilm (O'Toole and Kolter, 1998). To assess the ability of D-LL37 and L-LL-37 to stimulate twitching motility of $P$. aeruginosa (ATCC 19429), we tested the bacteria in the presence of these peptides. Both D- and L-LL-37 stimulated the rate of twitching motility (Figure 2D) at low concentrations of peptide $(4 \mu \mathrm{g} / \mathrm{ml})$. This significant $(p<0.01$, Student's $t$ test) increase in the rate of twitching on surface motility was 1.7 and $1.9 \mathrm{~mm} / \mathrm{h}$ on LB $(1 \%$ agarose) plates, for D- and L-LL-37, respectively. P. aeruginosa in the absence of peptide, was determined to have a twitching motility rate of $0.7 \mathrm{~mm} / \mathrm{h}$. LL-37 has been shown to have an insignificant effect on the swimming and swarming motility of $P$. aeruginosa PAO1 (Overhage et al., 2008); neither D- nor L-LL-37 appeared to effect swimming and swarming motility of $P$. aeruginosa (ATCC 19429) in this study (data not shown).

\section{RHAMNOSYLTRANSFERASES ARE DOWNREGULATED IN THE PRESENCE OF D- AND L-LL-37}

qRT-PCR was used to determine the total amount of $r h l A$ and $r h l B$ mRNA following treatment by of $1 \mu \mathrm{g} / \mathrm{ml}$ of either D- or L-LL-37. We determined that both peptides significantly downregulated the expression of these genes involved in the Rhl quorum sensing system in $P$. aeruginosa (ATCC 19429; Table 3). D-LL-37 had a -7.2 and -3.0 fold change in regulation of $r h l A$ and $r h l B$, respectively, relative to the control.

\section{SPECTRAL ANALYSIS OF THE SECONDARY STRUCTURE OF D- AND} L-LL-37

Circular dichroism spectra of the peptides were obtained for Dand L-LL-37. Pronounced dichroic minima at 222 and $208 \mathrm{~nm}$ are traits of helical peptides. Cathelcidins often exhibit little helical behavior at low concentrations in aqueous buffer (Johansson et al., 1998), assuming their most helical structure when in association with a biological membrane or a hydrophobic membrane mimic such as TFE, a strongly helix-promoting environment. The stable helical character when interacting with bacterial membranes may contribute to their potent anti-microbial activity (Park et al., 2004).

The spectra for L- and D-LL-37 in $10 \mathrm{mM}$ sodium phosphate ( $\mathrm{pH}$ 7.4) exhibit helical character, which is consistent with the results reported by Johansson et al. (1998). As was expected, the spectrum for D-LL-37 is the mirror image of that of the L-enantiomer (Figure 3A). Under these conditions, the conformation of L-LL-37 is estimated to have $28 \%$ alpha-helical content and that of D-LL-37 has $\sim 19 \%$ helical content. The spectra for both D- and L-LL-37 in 50\% TFE (a membrane mimic) in $10 \mathrm{mM}$ sodium phosphate ( $\mathrm{pH} 7.4$ ) show significantly greater helical character, $\sim 48 \%$ and $\sim 58 \%$, respectively. The helical content of these peptides was estimated based on their respective ellipticities at $208 \mathrm{~nm}$ using the method reported by Greenfield and Fasman (1969).

\section{D-LL-37 IS RESISTANT TO TRYPSIN}

Figure 3B shows the stability of the enantiomeric pair of peptides, D- and L-LL-37, in the presence of $0.05 \%$ trypsin, after incubation for $1 \mathrm{~h}$ at $37^{\circ} \mathrm{C}$. The L-form peptide, LL-37 at $200 \mu \mathrm{g} / \mathrm{ml}$, was $100 \%$ digested by the protease after the $1-\mathrm{h}$ incubation. D-LL-37 at $200 \mu \mathrm{g} / \mathrm{ml}$ showed no degradation in presence of trypsin with equal band intensities as quantified by densitometry (NIH ImageJ, data not shown).

\section{GALLERIA MELLONELLA INFECTION BY P. AERUGINOSA WITH AMP AND ANTIBIOTIC TREATMENTS}

The wax moth caterpillar Galleria mellonella infected with $P$. aeruginosa was used as a model in vivo system (Jander et al., 2000) to study the effectiveness of treatment with selected AMPs.

Table 3 | Pseudomonas aeruginosa genes downregulated in the presence of D- or L-LL-37.

\begin{tabular}{|c|c|c|c|c|c|}
\hline Treatment & Identification & Protein & Designation & Fold change & $p$-value \\
\hline L-LL-37 (1 $\mu \mathrm{g} / \mathrm{ml})$ & PA3479 & Rhamnosyltransferase chain A & $r h / A$ & -4.5 & $6.36 \mathrm{E}-03$ \\
\hline D-LL-37 $(1 \mu \mathrm{g} / \mathrm{ml})$ & PA3479 & Rhamnosyltransferase chain A & $r h / A$ & -3.0 & $4.11 \mathrm{E}-06$ \\
\hline
\end{tabular}

This table indicates the fold change (relative to the control) in regulation of $P$. aeruginosa genes rhlA and rhIB in the presence of $1 \mu \mathrm{g} / \mathrm{m} /$ of either $D$ - or $L-L L-37$ in biofilm. The relative levels of transcription was normalized by correcting for rpoD transcription levels. 


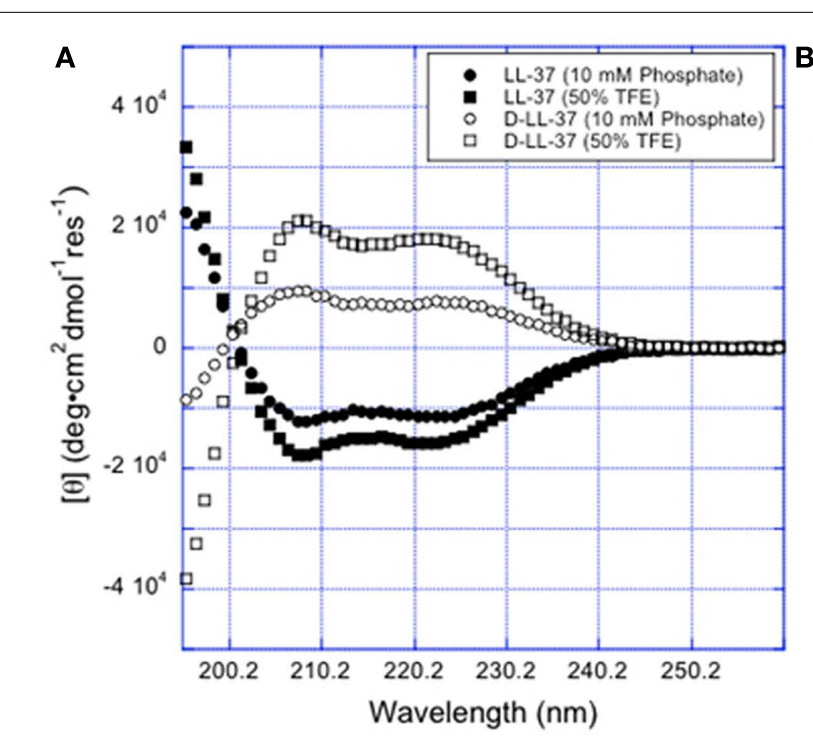

FIGURE 3 | Chirality affects D-LL-37 susceptibility to proteases. (A) The spectra for L- and D-LL-37 (125 $\mu \mathrm{M})$ exhibit significant helical character in $\mathrm{pH}=7.410 \mathrm{mM}$ sodium phosphate. As expected, the spectrum for D-LL-37 $(\mathbf{O})$ is the mirror image of that of the L-peptide (O). The spectra for both Dand L-LL-37 ( $\leq$ and,' respectively) become more intense when the peptides are in $50 \%$ TFE in $\mathrm{pH} 7.410 \mathrm{mM}$ phosphate, consistent with the peptides

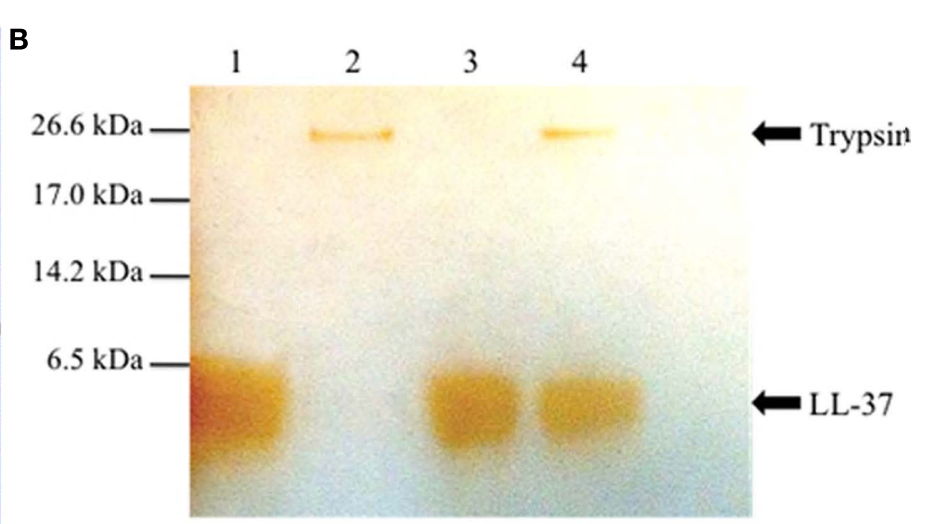

exhibiting more helical character. These results are consistent with what has been reported in the literature for these peptides. (B) D-LL-37 demonstrated resistance degradation by trypsin. Peptides $(18 \mu \mathrm{g})$ were dissolved in water $(90 \mu \mathrm{g})$ with either water or $0.05 \%$ trypsin $(10 \mu \mathrm{l})$ and incubated $\left(37^{\circ} \mathrm{C}, 1 \mathrm{~h}\right)$. $10 \mu \mathrm{l}$ aliquots were then taken, and a silver stain was performed. Lane 1 , LL-37; Lane 2, LL-37 with trypsin; Lane 3, D-LL-37; Lane 4, D-LL-37 with trypsin.
G. mellonella were infected with either $1 \times 10^{3} \mathrm{CFU}$ bacteria of $P$. aeruginosa (ATCC 19429) and immediately treated with a single dosing of $10 \mu \mathrm{l}$ PBS (no treatment control), $5 \mu \mathrm{g}$ ciprofloxacin, $10 \mu \mathrm{g}$ LL-37, $10 \mu \mathrm{g}$ D-LL-37, or $10 \mu \mathrm{g}$ NA-CATH:ATRA1-ATRA1 (data not shown; Figure 4). Multiple controls were utilized (PBS, and injections of non-infected $G$. mellonella with the treatment

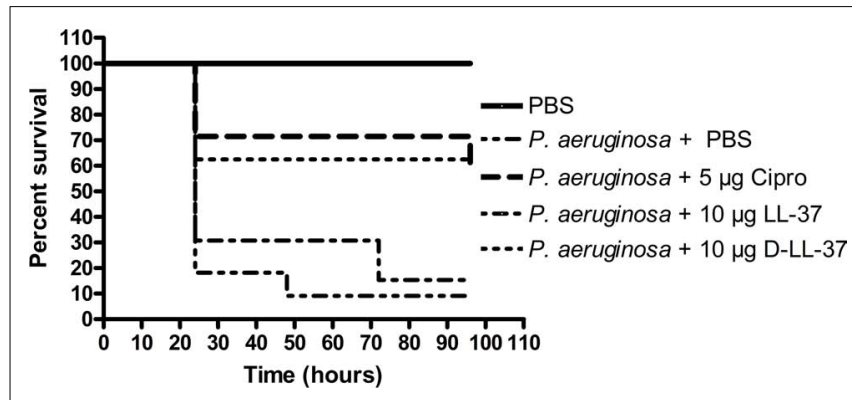

FIGURE 4 | Treatment of $P$ aeruginosa-infected $\boldsymbol{G}$. mellonella. D- and L-LL-37 significantly prolonged the survival of $G$. mellonella infected with $1 \times \mathbf{1 0}^{3} \mathbf{C F U} \boldsymbol{P}$ aeruginosa. Non-infected control groups consisted of a PBS injection, $5 \mu \mathrm{g}$ Ciprofloxacin injection, $10 \mu \mathrm{g}$ LL-37 injection, or a $10 \mu \mathrm{g}$ D-LL-37 injection. All non-infected groups fair similarly to the PBS only group (data not shown). The non-infected PBS only group experienced the highest survival rate and was significantly different from all other groups ( $p$-value $<0.002)$. The infected group without treatment failed to survive beyond $24 \mathrm{~h}$. A single dose of $5 \mu \mathrm{g}$ ciprofloxacin, or $10 \mu \mathrm{g}$ of either D- or L-LL-37 was found effective when compared to the infected control group ( $p$-value $<0.01$ ), but not different from each other overall. At 48 h D-LL-37 was found to be more effective than L-LL-37 ( $p$-value $<0.04$ )

NA-CATH:ATRA1-ATRA1 $(10(\mu \mathrm{g})$, also tested, was determined to be ineffective at prolonging survival, as this group failed to survive past $24 \mathrm{~h}$ (data not shown). used in the experiment) in order to measure the effects that the injection or the anti-microbials have on the host system. These negative controls had similar effects; no death was observed (data not shown). In the positive contol, no $P$. aeruginosa-infected G. mellonella survived beyond $24 \mathrm{~h}$. The ciprofloxacin $(60 \%)$ and D-LL-37 (60\%) treated groups demonstrated similarly prolonged survival ( $p$-value $<0.01$ ) and were not statistically different from each other overall. D-LL-37 was shown to be significantly more effective than LL-37 ( $p$-value $<0.01$ ) over the duration the experiment. NA-CATH:ATRA1-ATRA1 treatment did not improve survival, with all G. mellonella dead by $24 \mathrm{~h}$ (not shown). There was no significant difference in the survival rate between $\mathrm{D}$ - and L-LL-37.

\section{DISCUSSION}

In this study, we present novel peptides that address some of the challenges that have prevented the widespread use of AMPs. Among these concerns are the noted sensitivity of their antimicrobial activity to high salt concentrations (Goldman et al., 1997; Johansson et al., 1998) and the sensitivity of AMPs to bacterial and host secretions of proteases (Braff et al., 2005b). We describe the anti-microbial and anti-biofilm activity of these peptides.

We were able to demonstrate that LL-37 and its D-enantiomer, D-LL-37, NA-CATH, and NA-CATH-derived peptides have strong anti-microbial activity against the Gram-negative opportunistic pathogen, Pseudomonas aeruginosa. The effective peptides' EC50 values, when converted from $\mu \mathrm{g} / \mathrm{ml}$ to $\mu \mathrm{M}$ to reflect the number of molecules of peptide and to accommodate the different molecular weights of the peptides, ranged from 0.06 to $0.27 \mu \mathrm{M}$. The lowest EC50 belonged to NA-CATH:ATRA1-ATRA1, consistent with our prior observations for other bacteria (Dean et al., 2011). 
Based on earlier work (Amer et al., 2010; de Latour et al., 2010), we determined that when using SDS is as a model system for studying the structural properties of AMPs and their interaction with negatively charged membranes (Tack et al., 2002; Wang, 2008), that the degree of helical propensity had a significant correlation with anti-microbial activity. However, NA-CATH:ATRA1-ATRA1 and NA-CATH were ineffective in inhibiting biofilm formation despite being highly effective AMPs, and highly helical.

We were able to determine that both L- and D-LL-37 were able to inhibit the development of biofilms in two ways: through stimulatory activity in twitching motility assays, as well as antibiofilm activity in anti-biofilm assays. In confirmation with a previous study (Overhage et al., 2008), we demonstrated that LL-37 promotes twitching in P. aeruginosa. Twitching is a form of surface motility that is regulated by type IV pili (Whitchurch et al., 1991). LL-37 accomplished this increase in twitching by up-regulating genes related to this form of motility (Overhage et al., 2008), which in turn causes the bacteria to move instead of forming biofilm. This action has been shown to significantly lower the net mass of $P$. aeruginosa biofilm (Singh et al., 2002; Picioreanu et al., 2007). We have also demonstrated the equivalently stimulatory activity of D-LL-37 at increasing the rate of Pseudomonas surface motility. Thus, we believe that the ability of the peptides to stimulate twitching motility and thus inhibit biofilm formation in Pseudomonas is independent of peptide chirality.

Considering that the formation of biofilm protects bacteria during infections, such as in chronic wound and hospital-related pneumonia (Costerton et al., 1999; Prince, 2002; Dieter, 2004; Kaneko et al., 2007), the inhibition of biofilm formation by these AMPs is a critically important quality as a potential therapeutic, possibly more so than their anti-microbial activity. In our anti-biofilm assays, we were able to demonstrate that both L-LL-37 and D-LL-37 are capable of inhibiting $P$. aeruginosa biofilm formation to similar extents ( $\sim 50 \%$, Figures $2 \mathrm{~A}, \mathrm{C})$, this result compares well to other studies (Overhage et al., 2008). In addition, D-LL-37 downregulated rhlA and $r h l B$ gene expression to a similar extent as reported for L-LL-37 (Overhage et al., 2008), suggesting that they may share a conserved mechanism of action.

We have previously shown that LL-37, D-LL-37, NACATH:ATRA1-ATRA1, NA-CATH, and ATRA at concentration of $100 \mu \mathrm{g} / \mathrm{ml}$ elicited no significant hemolysis against red blood cells (de Latour et al., 2010; Dean et al., 2011), suggesting that these peptides have very low host-cell cytotoxic effects (Ryadnov et al., 2002).

To address the effectiveness of AMPs to thwart in vivo infection, we studied the abilities of select peptides in comparison to treatment with an established antibiotic in the wax moth caterpillar model system Galleria mellonella. G. mellonella has been shown to be a good model for the determination of the effects of virulence during infection by $P$. aeruginosa when compared to the mouse model (Jander et al., 2000). In this experiment, we determined that Pseudomonas-infected G. mellonella, when treated with ciprofloxacin, L-LL-37, and D-LL-37, have a significantly prolonged survival time when compared to the no-treatment control group. Further, D-LL-37 displays significant effectiveness when compared to the L-LL-37 and ciprofloxacin-treatment groups at $48 \mathrm{~h}$ (Figure 4). One interesting result is in the NA-CATH:ATRA1ATRA1-treatment group, when all of the caterpillars were dead at $24 \mathrm{~h}$, despite the peptide exhibiting strong in vitro anti-microbial activity. While NA-CATH:ATRA1-ATRA1 was determined to be the most effective AMP in our sodium phosphate study, it did not display anti-biofilm activity against $P$. aeruginosa. From this result, we suggest that the inability of NA-CATH:ATRA1-ATRA1 to prolong survival of G. mellonella could be attributed to the lack of anti-biofilm activity, thus exemplifying the importance of this anti-biofilm property for the potential AMP's future therapeutic applications.

Finally, we addressed the sensitivity of AMPs to proteolytic degradation. It has been shown for mammalian hosts and several bacteria, including $P$. aeruginosa and $S$. aureus, that they express proteases capable of degrading and inactivating LL-37 (Sieprawska-Lupa et al., 2004). In addition, other peptides that are capable of preventing the formation of biofilm, such as lactoferrin (Singh et al., 2002), are also degraded and inactivated in the presence of bacterial and host proteases. In our study, we have determined that the protease trypsin does not degrade D-LL-37 (Figure 3) while L-LL-37 is completely degraded and therefore experiences a loss of function. Protease resistance and the $\mathrm{CD}$ spectra are the two main aspects in which the chirality of the peptide appears to be critical. In all other aspects measured in this study, they are equivalent. This property of protease resistance may allow D-LL-37 peptide to remain active when applied to a wound despite protease production and therefore may be able to inhibit biofilm formation in vivo. We will test this hypothesis in future studies.

Novel treatments for chronic wounds, pneumonia, and medical implant-associated infections are critically needed. These infections are often characterized by polymicrobial infections by biofilm-forming bacteria, including $P$. aeruginosa (James et al., 2008, Murray, 2008). Desired characteristics of a novel therapeutic for these wounds would include a broad-spectrum, anti-biofilm treatment that is capable of withstanding the host environment, including protease secretions. We previously demonstrated the effectiveness of D-LL-37 to inhibit biofilm formation of S. aureus, another pathogen commonly found in infected wounds (Dean et al., 2011). In this work, we explore the ability of an enantiomer of a naturally occurring AMP to inhibit biofilm formation and treat infection by $P$. aeruginosa. D-LL-37 represents a potential therapeutic candidate by being a protease-resistant peptide that is effective in inhibiting biofilm formation, increasing the rate of twitching motility, and possesses potentially wound-healing properties toward the host (Picioreanu et al., 2007), while increasing the survival time of infected wax-moth caterpillars. For example, such a peptide may have potential to be developed as topical treatments for biofilm-forming bacteria in skin wounds, such as $P$. aeruginosa. It may be more appropriate to refer to these peptides as anti-biofilm peptides rather than AMPs, reflecting the current understanding of the role of biofilms in infection. Incorporation of anti-biofilm peptides or their synthetic derivatives in therapeutic topical applications may improve outcomes for infections ranging from chronic wounds, burns, implanted medical devices and pneumonia. 


\section{ACKNOWLEDGMENTS}

We thank Dr. George P. Anderson of the Center for Bio/Molecular Science and Engineering, Naval Research Laboratory, Washington, D.C. for the use of the CD spectrometer, and Melanie Juba for assistance in collecting and analyzing the CD spectra.

\section{REFERENCES}

Altman, H., Steinberg, D., Porat, Y., Mor, A., Fridman, D., Friedman, M., and Bachrach, G. (2006). In vitro assessment of antimicrobial peptides as potential agents against several oral bacteria. J. Antimicrob. Chemother. 58, 198-201.

Amer, L. S., Bishop, B. M., and van Hoek, M. L. (2010). Antimicrobial and antibiofilm activity of cathelicidins and short, synthetic peptides against Francisella. Biochem. Biophys. Res. Commun. 396, 246-251.

Bagge, N., Schuster, M., Hentzer, M., Ciofu, O., Givskov, M., Greenberg, E. P., and Høiby N. (2004). Pseudomonas aeruginosa biofilms exposed to imipenem exhibit changes in global gene expression and beta-lactamase and alginate production. Antimicrob. Agents Chemother. 48, 1175-1187.

Bals, R., Wang, X., Zasloff, M., and Wilson, J. M. (1998). The peptide antibiotic LL-37/hCAP-18 is expressed in epithelia of the human lung where it has broad antimicrobial activity at the airway surface. Proc. Natl. Acad. Sci. U.S.A. 95, 9541-9546.

Beckloff, N., Laube, D., Castro, T., Furgang, D., Park, S., Perlin, D., Clements, D., Tang, H., Scott, R. W., Tew, G. N., and Diamond, G. (2007). Activity of an antimicrobial peptide mimetic against planktonic and biofilm cultures of oral pathogens. Antimicrob. Agents Chemother. 51, 4125-4132.

Bone, R. C. (1993). Gram-negative sepsis: a dilemma of modern medicine. Clin. Microbiol. Rev. 6, 57-68.

Braff, M. H., Hawkins, M. A., Di Nardo, A., Lopez-Garcia, B., Howell, M. D., Wong, C., Lin, K., Streib, J. E., Dorschner, R., Leung, D. Y. M., and Gallo, R. L. (2005a). Structure-function relationships among human cathelicidin peptides: dissociation of antimicrobial properties from host immunostimulatory activities. $J$. Immunol. 174, 4271-4278.

Braff, M. H., Zaiou, M., Fierer, J., Nizet, V., and Gallo, R. L. (2005b). Keratinocyte production of cathelicidin provides direct activity against bacterial skin pathogens. Infect. Immun. 73, 6771-6781.
Bucki, R., Pastore, J. J., Randhawa, P., Vegners, R., Weiner, D. J., and Janmey, P. A. (2004). Antibacterial activities of rhodamine $\mathrm{B}$ conjugated gelsolin-derived peptides compared to those of the antimicrobial peptides cathelicidin LL37, magainin II, and melittin. Antimicrob. Agents Chemother. 48, 1526-1533.

Chennupati, S. K., Chiu, A. G., Tamashiro, E., Banks, C. A., Cohen, M. B., Bleier, B. S., Kofonow, J. M., Tam, E., and Cohen, N. A. (2009). Effects of an LL-37-derived antimicrobial peptide in an animal model of biofilm Pseudomonas sinusitis. Am. J. Rhinol. Allergy 23, 46-51.

Costerton, J. W., Stewart, P. S., and Greenberg, E. P. (1999). Bacterial biofilms: a common cause of persistent infections. Science 284, 1318-1322.

Cox, D. L., Sun, Y., Liu, H., Lehrer, R. I., and Shafer, W. M. (2003). Susceptibility of Treponema pallidum to host-derived antimicrobial peptides. Peptides 24, 1741-1746.

Dean, S. N., Bishop, B. M., and van Hoek, M. L. (2011). Natural and synthetic cathelicidin peptides with anti-microbial and anti-biofilm activity against Staphyloccus aureus. BMC Microbiol. 11, 114. PMID: 21605457. [Epub ahead of print].

de Latour, F. A., Amer, L. S., Papanstasiou, E. A., Bishop, B. M., and van Hoek, M. L. (2010). Antimicrobial activity of the Naja atra cathelicidin and related small peptides. Biochem. Biophys. Res. Commun. $396,825-830$.

Dieter, R. S. (2004). Coronary artery stent infection. Catheter. Cardiovasc. Interv. 62, 281 .

Donlan, R. M., and Costerton J. W. (2002). Biofilms: survival mechanisms of clinically relevant microorganisms. Clin. Microbiol. Rev. 15, 167-193.

Drenkard, E., and Ausubel F. M. (2002). Pseudomonas biofilm formation and antibiotic resistance are linked to phenotypic variation. Nature 416, 740-743.

Durham-Colleran, M. W., Verhoeven, A. B., and van Hoek, M. L. (2010) Francisella novicida forms in vitro biofilms mediated by an orphan response regulator. Microb. Ecol. 59, 457-465.

This project was supported by an Interdisciplinary Seed Grant to Monique L. van Hoek and Barney M. Bishop from the College of Science, George Mason University. Monique L. van Hoek was partially supported by Department of Energy grant DE-FC52-04NA25455.

Ganz, T., and Weiss J. (1997). Antimicrobial peptides of phagocytes and epithelia. Semin. Hematol. 34 , 343-354.

Gennaro, R., Scocchi, M., Merluzzi, L., and Zanetti, M. (1998). Biological characterization of a novel mammalian antimicrobial peptide. Biochim. Biophys. Acta 1425 361-368.

Goldman, M. J., Anderson, G. M. Stolzenberg, E. D., Kari, U. P., Zasloff, M., and Wilson, J. M. (1997). Human beta-defensin-1 is a salt-sensitive antibiotic in lung that is inactivated in cystic fibrosis. Cell 88, 553-560.

Gordon, Y. J., Huang, L. C. Romanowski, E. G., Yates, K. A., Proske, R. J., and McDermott AM. (2005). Human cathelicidin (LL-37), a multifunctional peptide, is expressed by ocular surface epithelia and has potent antibacterial and antiviral activity. Curr. Eye Res. 30, 385-394.

Greenfield, N., and Fasman G. D (1969). Computed circular dichroism spectra for the evaluation of protein conformation. Biochemistry 8 4108-4116.

Han, S., Bishop, B. M., and van Hoek, M. L. (2008). Antimicrobial activity of human beta-defensins and induction by Francisella. Biochem. Biophys. Res. Commun. 371, 670-674.

Hancock, R. E., and Speert D. P. (2000) Antibiotic resistance in Pseudomona aeruginosa: mechanisms and impact on treatment. Drug Resist. Updat. 3 , 247-255.

Hell, E., Giske, C. G., Nelson, A., Römling, U., and Marchini, G. (2010). Human cathelicidin peptide LL37 inhibits both attachment capability and biofilm formation of Staphylococcus epidermidis. Lett. Appl. Microbiol. 50, 211-215.

Heyland, D. K., Cook, D. J., Griffith, L., Keenan, S. P., and Brun-Buisson, C. (1999). The attributable morbidity and mortality of ventilatorassociated pneumonia in the critically ill patient. The Canadian Critical Trials Group. Am. J. Respir. Crit. Care Med. 159(Pt 1), 1249-1256.

Hoiby, N., Krogh Johansen, H., Moser C., Song, Z., Ciofu, O., and Kharazmi, A. (2001). Pseudomonas aeruginosa and the in vitro and in vivo biofilm mode of growth.
Microbes Infect. 3, 23-35.

James, G. A., Swogger, E., Wolcott, R. Pulcini, E., Secor, P., Sestrich, J., Costerton, J. W., and Stewart, P. S. (2008). Biofilms in chronic wounds. Wound Repair Regen. 16, 37-44.

Jander, G., Rahme, L. G., and Ausubel, F. M. (2000). Positive correlation between virulence of Pseudomonas aeruginosa mutants in mice and insects. J. Bacteriol. 182, 3843-3845.

Johansson, J., Gudmundsson, G. H., Rottenberg, M. E., Berndt, K D., and Agerberth, B. (1998). Conformation-dependent antibacterial activity of the naturally occurring human peptide LL-37. J. Biol. Chem. 273, 3718-3724.

Kaneko, Y., Thoendel, M., Olakanmi, O., Britigan, B. E., and Singh, P. K. (2007). The transition metal gallium disrupts Pseudomonas aeruginosa iron metabolism and has antimicrobial and antibiofilm activity. J. Clin. Invest. 117, 877-888.

Lee, K. H., Shin, S. Y., Hong, J. E., Yang, S. T., Kim, J. I., Hahm, K. S. and Kim, Y. (2003). Solution structure of termite-derived antimicrobial peptide, spinigerin, as determined in SDS micelle by NMR spectroscopy. Biochem. Biophys. Res. Commun. 309, 591-597.

Leszczynska, K., Namiot, A., Cruz, K. Byfield, F. J., Won, E., Mendez, G. Sokolowski, W., Savage, P. B., Bucki, R., and Janmey, P. A. (2011). Potential of ceragenin CSA-13 and its mixture with pluronic F-127 as treatment of topical bacterial infections. J. Appl. Microbiol. 110, 229-238.

Lopez-Leban, F., Kiran, M. D., Wolcott, R., and Balaban, N. (2010). Molecular mechanisms of RIP, an effective inhibitor of chronic infections. Int J. Artif. Organs 33, 582-589.

Maher, S., and McClean S. (2006). Investigation of the cytotoxicity of eukaryotic and prokaryotic antimicrobial peptides in intestinal epithelial cells in vitro. Biochem. Pharmacol. 71, 1289-1298.

May, T., Ito, A., and Okabe, S. (2009). Induction of multidrug resistance mechanism in Escherichia coli biofilms by interplay between tetracycline and ampicillin resistance genes Antimicrob. Agents Chemother. 53, 4628-4639. 
Moser, C., Weiner, D. J., Lysenko, E., Bals, R., Weiser, J. N., and Wilson, J. M. (2002). beta-Defensin 1 contributes to pulmonary innate immunity in mice. Infect. Immun. 70, 3068-3072.

Murray, C. K. (2008). Infectious disease complications of combat-related injuries. Crit. Care Med.36(7 Suppl), S358-S364.

Nizet, V., Ohtake, T., Lauth, X., Trowbridge, J., Rudisill, J., Dorschner, R. A., Pestonjamasp, V., Piraino, J., Huttner, K., and Gallo, R. L. (2001). Innate antimicrobial peptide protects the skin from invasive bacterial infection. Nature 414, 454-457.

Oldak, E., and Trafny E. A. (2005). Secretion of proteases by Pseudomonas aeruginosa biofilms exposed to ciprofloxacin. Antimicrob. Agents Chemother. 49, 3281-3288.

O’Toole, G. A., and Kolter R. (1998). Flagellar and twitching motility are necessary for Pseudomonas aeruginosa biofilm development. Mol. Microbiol. 30, 295-304.

Ouhara, K., Komatsuzawa, H., Kawai, T., Nishi, H., Fujiwara, T., Fujiue, Y., Kuwabara, M., Sayama, K., Hashimoto, K., and Sugai, M. (2008). Increased resistance to cationic antimicrobial peptide LL37 in methicillin-resistant strains of Staphylococcus aureus. J. Antimicrob. Chemother. 61, 1266-1269.

Overhage, J., Campisano, A., Bains, M., Torfs, E. C., Rehm, B. H., and Hancock, R. E. (2008). Human host defense peptide LL-37 prevents bacterial biofilm formation. Infect. Immun. 76, 4176-4182.

Papanastasiou, E. A., Hua, Q., Sandouk, A., Son, U. H., Christenson, A. J., Van Hoek, M. L., and Bishop, B. M. (2009). Role of acetylation and charge in antimicrobial peptides based on human beta-defensin-3. APMIS 117, 492-499.

Park, I. Y., Cho, J. H., Kim, K. S., Kim, Y. B., Kim, M. S., and Kim, S. C. (2004). Helix stability confers salt resistance upon helical antimicrobial peptides. J. Biol. Chem. 279, 13896-13901.

Picioreanu, C., Kreft, J. U., Klausen, M., Haagensen, J. A., Tolker-Nielsen, T., and Molin, S. (2007). Microbial motility involvement in biofilm structure formation - a 3D modelling study. Water Sci. Technol. 55, 337-343.

Pollard, J., Wright, J., Feng, Y., Geng, D., Genberg, C., and Savag, P. B.
(2009). Activities of ceragenin CSA13 against established biofilms in an in vitro model of catheter decolonization. Antilnfect Agents Med. Chem. 8, 290-294.

Prince, A. S. (2002). Biofilms, antimicrobial resistance, and airway infection. N. Engl. J. Med. 347, 1110-1111.

Rachid, S., Ohlsen, K., Witte, W., Hacker, J., and Ziebuhr, W. (2000). Effect of subinhibitory antibiotic concentrations on polysaccharide intercellular adhesin expression in biofilmforming Staphylococcus epidermidis. Antimicrob. Agents Chemother. 44, 3357-3363.

Rello, J., Ausina, V., Ricart, M., Castella, J., and Prats, G. (1993). Impact of previous antimicrobial therapy on the etiology and outcome of ventilator-associated pneumonia. Chest 104, 1230-1235.

Ressner, R. A., Murray, C. K., Griffith, M. E., Rasnake, M. S., Hospenthal, D. R., and Wolf, S. E. (2008). Outcomes of bacteremia in burn patients involved in combat operations overseas. J. Am. Coll. Surg. 206, 439-444.

Richards, M. J., Edwards, J. R., Culver, D. H., and Gaynes, R. P. (1999). Nosocomial infections in medical intensive care units in the United States. National Nosocomial Infections Surveillance System. Crit. Care Med. 27, 887-892.

Ryadnov, M. G., Degtyareva, O. V., Kashparov, I. A., and Mitin, Y. V. (2002). A new synthetic all-D-peptide with high bacterial and low mammalian cytotoxicity. Peptides 23, 1869-1871.

Saiman, L., Tabibi, S., Starner, T. D., San Gabriel, P., Winokur, P. L., Jia, H. P., McCray, P. B. Jr., and Tack, B. F. (2001). Cathelicidin peptides inhibit multiply antibiotic-resistant pathogens from patients with cystic fibrosis. Antimicrob. Agents Chemother. 45, 2838-2844.

Sieprawska-Lupa, M., Mydel, P., Krawczyk, K., Wójcik, K., Puklo, M., Lupa, B., Suder, P., Silberring, J., Reed, M., Pohl, J., Shafer, W., McAleese, F., Foster, T., Travis, J., and Potempa, J. (2004). Degradation of human antimicrobial peptide LL-37 by Staphylococcus aureus-derived proteinases. Antimicrob. Agents Chemother. 48, 4673-4679.

Singh, P. K., Parsek, M. R., Greenberg, E. P., and Welsh, M. J. (2002). A component of innate immunity prevents bacterial biofilm development. Nature 417, 552-555.

Sorensen, O., Cowland, J. B., Askaa J., and Borregaard, N. (1997). An ELISA for hCAP-18, the cathelicidin present in human neutrophils and plasma. J. Immunol. Methods 206, 53-59.

Stewart, P. S., Rayner, J., Roe, F., and Rees, W. M. (2001). Biofilm penetration and disinfection efficacy of alkaline hypochlorite and chlorosulfamates. J. Appl. Microbiol. 91, 525-532.

Tack, B. F., Sawai, M. V., Kearney, W. R., Robertson, A. D., Sherman, M. A., Wang, W., Hong, T., Boo, L. M., Wu, H., Waring, A. J., and Lehrer, R. I. (2002). SMAP-29 has two LPS-binding sites and a central hinge. Eur. J. Biochem. 269, 1181-1189.

Travis, S. M., Anderson, N. N., Forsyth, W. R., Espiritu, C., Conway, B. D., Greenberg, E. P., McCray, P. B. Jr., Lehrer, R. I., Welsh, M. J., and Tack, B. F. (2000). Bactericidal activity of mammalian cathelicidinderived peptides. Infect. Immun. 68 2748-2755.

Turner, J., Cho, Y., Dinh, N. N., Waring, A. J., and Lehrer, R. I. (1998). Activities of LL-37, a cathelin-associated antimicrobial peptide of human neutrophils. Antimicrob. Agents Chemother. 42, 2206-2214.

Van Delden, C., and Iglewski B. H. (1998). Cell-to-cell signaling and Pseudomonas aeruginosa infections. Emerging Infect. Dis. 4, 551-560.

Wade, D., Boman, A., Wåhlin, B., Drain, C. M., Andreu, D., Boman, H. G., and Merrifield, R. B. (1990). All-D amino acid-containing channel-forming antibiotic peptides. Proc. Natl. Acad. Sci. U.S.A 87, 4761-4765.

Wang, G. (2008). Structures of human host defense cathelicidin LL-37 and its smallest antimicrobial peptide KR-12 in lipid micelles. J. Biol. Chem. 283, 32637-32643.

Wang, Y., Hong, J., Liu, X., Yang, H., Liu, R., Wu, J., Wang, A., Lin, D., and Lai, R. (2008). Snake cathelicidin from Bungarus fasciatus is a potent peptide antibiotics. PLoS ONE 3, e3217. doi: 10.1371/journal. pone. 0003217

Whatley, W. S., Chandra, R. K., and MacDonald, C. B. (2006). Systemic absorption of gentamicin nasal irrigations. Am. J. Rhinol. 20, 251-254.

Whitchurch, C. B., Hobbs, M., Livingston, S. P., Krishnapillai, V., and Mattick, J. S. (1991). Characterisation of a Pseudomonas aeruginosa twitching motility gene and evidence for a specialised protein export system widespread in eubacteria. Gene 101, 33-44.

Wilson, C. L., Ouellette, A. J., Satchell, D. P., Ayabe, T., López-Boado, Y. S., Stratman, J. L., Hultgren, S. J., Matrisian, L. M., and Parks, W. C. (1999). Regulation of intestinal alpha-defensin activation by the metalloproteinase matrilysin in innate host defense. Science 286, 113-117.

Yasin, B., Wang, W., Pang, M., Cheshenko, N., Hong, T., Waring, A. J., Herold, B. C., Wagar, E. A., and Lehrer, R. I. (2004). Theta defensins protect cells from infection by herpes simplex virus by inhibiting viral adhesion and entry. J. Virol. 78, 5147-5156.

Zasloff, M. (2002). Antimicrobial peptides of multicellular organisms. Nature 415, 389-395.

Zhao, H., Gan, T. X., Liu, X. D., Jin, Y., Lee, W. H., Shen, J. H., and Zhang, Y. (2008). Identification and characterization of novel reptile cathelicidins from elapid snakes. Peptides 29, 1685-1691.

Conflict of Interest Statement: The authors declare that the research was conducted in the absence of any commercial or financial relationships that could be construed as a potential conflict of interest.

Received: 01 March 2011; paper pending published: 04 April 2011; accepted: 24 May 2011; published online: 04 July 2011. Citation: Dean SN, Bishop BM and van Hoek ML (2011) Susceptibility of Pseudomonas aeruginosa biofilm to alpha-helical peptides: D-enantiomer of LL-37. Front. Microbio. 2:128. doi: 10.3389/fmicb.2011.00128

This article was submitted to Frontiers in Cellular and Infection Microbiology, a specialty of Frontiers in Microbiology. Copyright (C) 2011 Dean, Bishop and van Hoek. This is an open-access article subject to a non-exclusive license between the authors and Frontiers Media SA, which permits use, distribution and reproduction in other forums, provided the original authors and source are credited and other Frontiers conditions are complied with. 